\title{
Position Function And Legal Advisorsin The Criminal Justice System In Indonesia
}

\author{
Dr (Cand). Drs. Muzakkir, SH., MH., M.Pd \\ (Prof. Dr. H. Hasballah Thaib, MA Prof. Dr. Suhaidi, SH.,MH. Dr. Zulkarnaini \\ Abdullah, MA \\ Legal science doctoral student, Faculty of Law, University of Sumatera Utara, Medan, Indonesia)
}

\begin{abstract}
Law in our society increasingly required its presence, especially in the era of globalization are dating. The existence of laws meant to be especially important, considering that our country is still at the state level prismatic, which is a country that sits between an agricultural country and industrialized countries. In this transition state, the need for a companion/legal counsel in handling cases faced by the people of Indonesia as a whole more strongly felt. Legitimacy handling of Criminal Procedure Law in Indonesia has been legislated in Act No. 8 of 1981 on the book of the Law of Criminal Law (Penal Code) and various regulatory events in the Law for Special Crimes. However, in practice the implementation of the Act is contrary to the purpose of establishing the Criminal Code itself, because it is still faced with the bureaucratic institutions of investigation.
\end{abstract}

Keywords: KUHP (Criminal Procedure Law), lawyer (legal advisor)

\section{INTRODUCTION}

Legal counsel is one part of the law enforcement in the Indonesian criminal law system other than judges, prosecutors and legal counsel kepolisian.Peranan in helping people to get justice is needed.In the developing countries or the developing countries, which make the arrangement and changes in various fields, mainly from agricultural country to country indusri, cause a lot of social problematics, both involving a shift in values, and work space as well as changes to the community. Thus the legal counsel is needed as a companion in addressing various issues of law or legal cases that occur.Another issue which is also very into the problems in developing societies transition to advanced and modern society is related to the level of economic growth and development of society. Where people with limited economic capabilities are very difficult to be able to hire a lawyer in a legal case that it faces mmembela. Not to mention the legal adviser who was also relatively very few in number and cost required to hire is relatively expensive.

In criminal law enforcement in Indonesia the presence of legal counsel also referred to the defenders or Advocates has already been acknowledged, as contained in Act No. 8 of 1981 on the Law of Criminal Procedure Code (Criminal Code). The Act greatly respect and appreciate the function and human rights (HAM) .In disclose material truth indispensable role of legal counsel as set in criminal law. The definition of legal counsel in Indonesia experienced many penafsiran.Pengertian about penassehat law in Indonesia belaum no agreement because there is no law regulating legal counsel or assistance hukum.Undang the Law on Criminal Procedure in article 1 point to 3 states, "A legal counsel is a person who fulfills the conditions prescribed by or under the Act to provide legal assistance "(Ramaddon, 1982).Profession legal counsel in the course of law enforcement there are two profesii pengacara.Selain advocates and professions, the profession of legal counsel is also run by bbiroagency or agencies of the law on public agencies. The term used for legal counsel that the court proceedings in the existing Law No. 13 Year 1965 About the Court Courts In General And the Supreme Court. Law was later repealed by Act No. 14 of 1985. In Act No. 13 of 1965 Article 54 pensehat understanding of the law reads: "Legal Counsel are those who perform activities mmemberikan legal advice relating to a process before the courts" , Based on such understanding, then the task of legal counsel only provide the necessary legal advice to his client (client). When seen in practice, duty counsel a lawyer much luas.Penasehat law can represent the interests of his client before the court in a civil case, the submitted documents, evidence and witnesses, or may also file an appeal, an appeal or review back, a lawyer can appear as defenders.Based on the Joint Decree (SKB) Chairman of the Supreme Court of the Republic of Indonesia and the Minister of Justice of the Republic of Indonesia dated 6 July 1987 Number: KMH / 005 / SKB / VII / 1987 on Procedures for Monitoring Education and Defense Self Defense Counsel, Article 1 point 2 is formulated as follows "Legal counsel are those that provide assistance or legal advice, either denngan join or not, in a community of lawyers, both as a livelihood or not, which is referred to as a lawyer / Advocates and lawyers practice". 
Advocates with the duties and functions of a practicing lawyer is not much different. Advocates and lawyers and the practice has a particular domicile, as set in the decree of appointment and practice permit issued by the Chairman of the local High Court. Having obtained the decree of appointment, advocates and lawyers practicing his profession obliged to take an oath at the High Court Chief hadappan locals. Furthermore enroll on the Registrar of the High Court and the District Court at the place specified.There is a difference between Advocates and lawyers practice, Advocates appointed by the Minister of Justice to be able to conduct practice law anywhere in the territory of the Republic of Indonesia, while practicing lawyer appointed by the Chairman of the High Court and only mmelakukan local law practice activities within the jurisdiction of the High Court concerned.The function and position of legal adviser in the justice system in Indonesia, generally regulated in Law Number 14 of 1970 article 35, which reads, "Every person who lodged the case entitled to a lawsuit". Article 36 reads: "In a criminal case of a suspect, especially since the time of the arrests and or detention shall be entitled to call and request assistance legal adviser" (Abikusumo, 1994). Thus lawyers are an integral part in the criminal justice system in Indonesia.Given the function and position of legal counsel is so important, then it is appropriate rights and obligations of legal counsel emphasized, both in the justice system and outside the justice system. This is intended to create a rule of conduct of the judicial system are obvious. For it is necessary to study the code of professional conduct legal advisor in order judicial system prevailing in Indonesia at this time.

Relative to the above, related to the function and position of legal counsel in the criminal justice system in Indonesia, it is important to also learn and gain a clear understanding of and their right to legal counsel in the criminal justice system in Indonesia function and position of legal adviser in the criminal justice system in Indonesia.

\section{Profession and Legal Counsel}

Legal advisor profession is providing services in the field of law to its clients who have legal problems, with or without compensation materiil.Dalam profession, lawyers sometimes have conflicting interests or conflict of interest with fellow peers, either by alliance or by the courts and agencies officials, or the concerns and complaints of the seekers of justice, which can have disastrous consequences both material and moral damages for clients and legal counsel in the form of loss of reputation, honor and dignity.To ensure the interests of the public, those seeking justice dank lien, as well as the interests of the good name, honor and dignity of the institution penaehat law itself, it is necessary to have a rule roles or code of ethics counsel should be held as an absolute necessity and complied with by all legal advisor in the conduct of his profession. Organization of Legal Counsel in Indonesiia since its inception until saad can be found among others: the Association of Indonesian Advocates (PERADI), Association of Indonesian Advocates (PAI), the Association of Indonesian Advocates (AAI), the Association of Indonesian Advocates (IKADIN), Ikatam Legal Advisor Indonesia (IPHI), which already has a code of ethics and establish profesii in the statutes / by-laws. Although the code of ethics of each organization Advocates are different, yet the content of the material remains the same.The code of ethics is the provision of legal counsel / norms regulating every behavior and actions that can and can not be done by a legal counsel in the course of his profession, both during proceedings before the court and out of court. Basically, compliance and adherence to the code of a legal representative ettik profession based on moral awareness in their own destiny. However, in case of infringement ettik code, it is possible subject to administrative sanctions and criminal penalties as well as kepiidanaan which is civil in nature. Codes of ethics counsel can be grouped as follows:

1. The code of conduct relating to the attitude and behavior or personality of legal advisers in general.

2. The code of ethics in the attorney-client relationship

3. he code of conduct in relation to legal advisors with colleagues legal counsel

4. The code of conduct in relations with the opposition legal counsel

5. The code of conduct in relation penaasehat law against the law, the Constitution, the rule of law, the judiciary and officials.

In relation to personality problems Advocates, described in the Advocates Act of 2003 Article 1 Code of conduct Advocates, that Advocates in performing his duties should always uphold high judicial functions. In connection with that, Article 1, paragraph (2) of the importance of self-image contains Advocates, Advocates stated that in his life may not perform acts that do not fit ddengan norms and shall have the honor and personal behavior are not defective. The same thing is also defined in the Act No. 14 of 1970 on the provisions of the Basic Judicial Authority, article 37 of the Attitude, Behavior / Personality. Legal counsel to provide legal assistance in accordance with Article 37 above, legal counsel to help expedite the case by upholding the function of Pancasila, the law and justice. (Abikusno, 1994)

In addition to the provisions stated above, there are also other provisions that regulate the behavior and personality of legal counsel in rumussan oath legal counsel:

1. Faithful and practice Pancasila, the Constitution of 1945 and any Act in force in the Republic of Indonesia; 
2. Acting truthfully based on law and justice;

3. Maintaining behavior and obligations in accordance with the obligations, honor, dignity and responsibility;

4. It will not defend or memberinassehat law in a case that according to your feelings / thoughts can not give confidence in the defense under the law.

Problems attorney-client relationship are set in the Code of Indonesian Advocates passed on May 23, 2002 in Article 4 to denngan Article 9. In this case Advocates are practicing a profession based kaedah trust of kliennnya, shall keep confidential all corporate clients, as well as in matters of honor is not the most important thing in a relationship between the attorney-kliennya.Advokad has a right of retention (save) files are handled. If the client does not meet its financial obligations, Advocates are not allowed to ask for the client.

Maintain a good relationship with the client is the absolute duty of a legal representative because besides being a source of income, also profession legal counsel is trust services from those seeking justice in upholding the law and justice, not to the clients that telalh gives credence to the lawyers feel that their interests be ignored, especially trust given by the client was abused.

In addition, the code of conduct prohibits attorneys gave a promise to clients that the case is entrusted will win attau-yet another promise of hope, legal counsel may only be declared to their clients that would be deployed efforts and the ability to win his case, as in the code of conduct does not allowed for legal counsel held engineering with the other parties in the case are handled. Example, did not present evidence that could have important and need to be filed, or not filed a legal action in the interests of its clients tersebut.Dalam code of conduct contained in the oath of office, it is not permissible for lawyers to handle a case that according to estimates or belief that the case was not based on law.

In conjunction with fellow attorneys must respect each other and appreciate each other, either in the same container or in different containers and different professional organizations, but equally practicing a profession as legal counsel.If the legal counsel in handling a case of divergence of menilaisuatu legal facts and application of the law, then each party shall respect and appreciate the position and duties of each. The difference of opinion is a reasonable and which will be submitted to kien took this decision.

\section{Rights Legal Counsel}

Position and function of legal advisers are set in the Criminal Procedure Code which codified the Criminal Procedure Code in Indonesia, article 69 Criminal Code, reads: "Legal representation is entitled to contact the suspect since arrested or detained at all levels of examination according to the procedures specified in the Act this". (Ramadlon, 1982)

The core section 69 Criminal Procedure Code above that can take care klein legal counsel in a criminal case, from now on catching up with the detention, both at the level of the examination of investigation, examination of the prosecutor, or-even at the court examination. This Article is closely related to the rights of suspects and obligations of law enforcement. In Article 57 the Criminal Procedure Code in the unloading: "The defendant is subject to arrest entitled to contact his legal counsel in accordance with the provisions of this law".

KUHAP upholds human rights, but in practice the implementation of Article 57 Criminal Code of the rights of the accused is contrary to the goal, despite the fact that the right to contact the suspect is a right guaranteed by law. This is due to legal counsel'll have to go deal with the bureaucracy and the investigator were quite difficult to penetrate. It arises because of a violation of article that regulates the right to contact their supervisor or contacted tersangkka or the rights of suspects are not at threatening others with a criminal or administrative sanctions.

Legal adviser only allowed to contact the suspect in office hours, the rest are not allowed. This is a violation of the right to legal counsel and suspects. Whereas the inspections on suspect must be accompanied by legal counsel. But sometimes investigators conduct an examination of the suspect outside of the office / department. As a result, the suspect at the time of the examination is not accompanied by a legal advisor. Against this investigator no form of sanctions instructions assigned to it ..Legal counsel in investigations that are in a weak position, because the position of legal counsel will be against or contrary to the investigators, that in practice the implementation of the investigation is dominated by the investigator corps. Legal counsel often in view of disrupting penyidikan.Oleh therefore, be prohibited its presence to accompany clients on the status of the suspect. It is contained in article 70 of the Criminal Code as follows:

1. The legal advisors as referred to in Article 69 is entitled to contact and speak with the suspect at every level of examination and any time for the benefit of the defense case.

2. If there is evidence that the legal counsel is misusing the right, in conversation with the suspect in accordance with the level of scrutiny, investigators, prosecutors or prison staff to give a warning to the legal counsel.

3. If the warning is not heeded, then the relationship is supervised by officials specified in paragraph (2).

4.If, after being watched, their rights are still abused, then the relationship is witnessed by the official in paragraph (2) and thereafter continued to be violated if the relationship is further prohibited 
Under the draft position of legal advisor in each process is not balanced with Kedukan law enforcement agencies, for example: the police and the judiciary. It is set in article 71 Criminal Code, as follows:

1. he legal advisors in the levels of checks have not been in touch with the suspect and supervised by the investigator, prosecutor or prison staff.

2. In the case of crimes against the security of the State, the official in paragraph (1) can hear the contents of the conversation. (Ramadlon, 1982) Of Article 71 above locates the position of legal counsel is very low and weak because its presence is always the suspect, but did not rule out the possibility the investigator, the prosecutor or the accused prison staff suspected matters with a legal representative. In such situations counsel can not do anything because it can not provide a decisive response. Looked here less balanced position of legal adviser either with the investigator or prosecutor.The Book of the Law of Criminal Law Article 71 paragraph (2) in relation to the confidential nature of duty counsel, legal counsel or Advocates set in the code of conduct concerning the confidential nature of which is also in need of correction and improvement both inside and outside the court. The provisions set forth in Article 71 paragraph (2) Criminal Procedure prejudice to the rights of legal counsel or confidential immunitas Advocates and displaced. If the implementation of the law associated with the security of the State, the activities that materially not put pressure on the country's security, but if the investigator considers such actions violate the security of the state, the police did not care about it anymore.

Confidentiality duty legal counsel, freedom and secrecy of his relationship with the suspect is also not guaranteed, particularly in relation to correspondence contained in the Criminal Procedure Code article 62 paragraph as follows:

1. The suspect or accused has the right to send a letter to the legal adviser, and received a letter from legal counsel and relatives whenever needed by him, for this purpose for the suspect or the accused is provided stationary.

2. Correspondence between the suspect or the accused with legal counsel or relatives are not examined by the investigator, prosecutor, judge or an official of a detention unless there is sufficient reason to suspected that the correspondence was abused.

3. In a letter to the suspect or the accused traced or examined by the investigator, prosecutor, judge or an official of a detention center, it was told the suspect or defendant and the letter sent back to the sender after a stamp that reads "has been traced".

He nature of the confidentiality of legal counsel / Advocates are regulated in article 62 and article 71 Criminal Code very seimbanng or synchronized with secrecy belongs to the investigator. Particularly in investigating and investigating cases related to state security, legal counsel was not allowed to hear the conversation, sebagaiman are set in section 115 Criminal Procedure Code the following verses:

1. In the event that investigators were carrying out an examination of the suspect, legal counsel can follow the course pemerriksaan by seeing and hearing examinations.

2. In the case of crimes against state security, legal counsel may present a way to see, but can not hear the examination. (Ramadlon, 1982)

From the foregoing article, clearly hinting strongly that limit the confidentiality of legal counsel / advokad.Hal This resulted in an imbalance between the guaranteed confidentiality of investigators and legal advisors. At the time of the trial that was held at the district court level, all parties are required to maintain order and dignity of the court. In practice, this provision is concerned with the defendant and counsel / Advocates. Legal adviser / Advocates and the accused became the center of special attention from the judge during the hearing, as if the two sides could be considered as a source of unrest in court. While prosecutors and judges are treated differently in the trial process, should all parties involved in the trial received the same attention and treatment.Legal counsel banned confuse dissent with emotional acts or attacks on personal reputation and honor of other legal counsel. The legal advisors working on the basis of trust of klienya.Ia represent the interests of its clients, both outside and inside the court. Therefore, lawyers should act lakuyang good, responsible, upholding the law, respect the rights of the other party's decision, and should not be threatening or harassing others. Code of conduct prohibit lawyers / Advocates held engineering and other parties that may or could cause harm to his client. Under the law a case may make peace should his client's permission.

Besides, the lawyer shall respect the general powers of the judiciary and its officials. Understanding the general rule is referred to in Article 92 Criminal Code, which reads as follows:

1. The definition of officials, including those who are chosen in elections held by the general rules, as well as people who are not selected for the election, a member of the formation of the body of laws, governmental agencies or representatives of the people, which was formed by the government or on behalf of the government, as well as all members of the board of subak, and all the heads of the people of Indonesia native and foreign heads of eastern group, which runs the legitimate power;

2. The so-called officials and judges as well as judges referee, called the judge as well as the people who run the administrative court, as well as the chairmen and members of the religious courts; (Moelyatno, 1985) 
Included in the general rule is the prosecutor and investigator, whereas what is meant by the judiciary and environmental officials, including all judicial Indonesia and its officials, namely judges, clerks, bailiffs, and ranking officials clerkships.

Dishonoring the judiciary and officials said as the act of insulting the court (contemp of court) Until now Indonesia has no law on contempt of court. But in general explanation point 4 of Law No. 14 Year 1985 regarding the Supreme Court, mentioned about it. Similarly, the National Working Meeting (Rakernas) The Supreme Court of 1986 have been grouped actions legal counsel considered as contempt of court, namely:

1. In the oral and written has issued a statement or opinion is an act punishable by criminal;

2. Shows disrespectful attitude towards the tribunal or other judicial officials, for example:

3. Leaving the courtroom,

4. Do not answer any questions the judge when asked by the judge;

5. Ignoring the interests of the requester of legal aid;

6. Using inappropriate words against the Law / Government;

7. Acting behavior and actions are not worthy of the parties litigant or counsel.

\section{Function and Legal Standing Advisory}

As well as other law enforcement investigators / police, function and position of prosecutors and judges should be protected. In the criminal justice system in Indonesia, the protection function and position of legal counsel contained in the provisions of Article 170 of the Criminal Code. However, this article is only related to the protection of confidentiality of office as a witness, as the provisions in the article as follows: "Those who because of work dignitary or position are obliged to storage the secret can be requested relieved of the obligation to give testimony, which is about entrusted to them". (Romadlon, 1982) provisions are clearly guarantees for maintaining the confidentiality of legal counsel positions, in accordance with the code of conduct of office.

If tied to the provisions of Article 108 paragraph (2) Criminal Code, Article 170 of the Criminal Code was not running above absolute. Article 108 Paragraph (2) contains: "Anyone who knows conspiracy to commit a criminal act against peace and safety of the public or against persons or against property instantly reported the matter". (Romadlon, 1982)

With these provisions need to be questioned about the position and office of legal counsel, because in this position to have two (2) side, ie as a legal advisor who shall maintain the confidentiality of office, and on the other hand the position as citizens. It would be a problem if the parties agree is a client of the adviser to the law itself. Solving the problem is not easy, having to deal with two (2) different provisions. Under no circumstances shall legal counsel shall maintain the confidentiality of office. However, the circumstances or events that do not involve the provision of office or infraction, the obligation as a citizen, must be upheld. Basically Article 108 paragraph two (2) of the Criminal Code will reduce the dignity of the office of legal counsel, as long as it does not concern directly with the work of legal counsel.In line with the above, the position of legal counsel have the nature of specificity, ie its existence not only sebgai legal aid, but also as a legal aid service.Legal asistence and legal means legal counsel position as a service provider in the field of law to a person involved in a case or cases, Provision of services / legal aid is exempted from legal aid to people who can not afford, so the main concept of legal aid is given bentuan law by way of defending the interests and the rights of little people. Legal assistance invite a broad understanding of legal aid, because besides containing the sense and purpose of providing legal aid services, both to those who can afford achievement also provide legal assistance to the poor for free. Then legal service stresses the corner luas.Pengertian legal services within the meaning of this broader legal services from legal aid and legal assistance.With such a position, then legal counsel indeed deserves a position in the criminal justice process is safe and maintained her dignity. Profession legal counsel facilitator not a profession, but more than that profession legal counsel should have to get a fairly respectable, with his duties and protected.Given the position and function of legal counsel is not only limited to legal aid, legal assistance, as well as legal service, it must be understood his position is an integral part of the judicial process, both for the non-poor and can not afford. Law enforcement, in particular the respect and giving notch function legal counsel, is very important as where it was revealed in the phrase: "Concretely one of these efforts is the formulation of criminal procedural law, national as stipulated in Law No. 8 of 1981 and which was in essence a the procurement reform effort codification of law (criminal procedure) nationwide, to accommodate the appropriate law enforcement agencies policing functions and authority, to implement the demands of skill enhancement and improvement of the mental attitude of law enforcement officers, as well as to make legal aid as one of the pillar of the national criminal procedural law ". (Anonymous, 1982).

As a pillar of the national criminal law, then it is fitting function and position of legal aid, as well as legal counsel to get the position accordingly, because if one part of the position lower than the position of other fields, it will lead to one goal Criminal Code, which seeks to provide welfare, will be difficult to achieve. 
Adequate protection of the attitude and advocate positions, in essence helps build the human rights of the people, because in this case the position of the people represented by legal counsel.

Another issue is the protection of the rights of departure for legal counsel assigned to the case by the district court. Of suspects / defendants who can not afford legal assistance may be requested as provided for in article 56 of the Criminal Code:

1. In the case of a suspect or a defendant suspected of or charged with a criminal offense punishable by the death penalty or a penalty of 15 (fifteen) years or more, or for those who can not afford is punishable by five (5) years or more who do not have Counsellor, officials are concerned at the level of examination in the proceedings shall appoint counsel for them.

2. Medium attorneys appointed to act as intended in paragraph (1) provide assistance free of charge. (Romadlon, 1982).

This issue is also questionable, namely concerning the relation with the oath of office advocate himself or the promise of a practicing lawyer, Diman mentioned in the oath of office is not justified to defend against those cases that require the implementation is not based on the law at all. If a lawyer or a practicing lawyer gets the appointment of the court, to defend a case, which according to the case is not based on the law, whether it can declare his starting right? In practice it is highly unlikely to do.

Attorneys refused to accompany clients on appointment of district court, in practice rarely received the protection of the rights of reject such, because after all legal advisor is almost impossible to reject, since it relates weight to the problem of its agreement to become a legal advisor area High Court that ,

Protection of legal counsel appears inadequate, either to the rights that are active, and the rights that are passive, so therefore it is necessary to bear in mind how to sit in the actual position. Law enforcement can not be separated from the position of legal adviser, as revealed by Chambliss and Seidman that basically fortunately law enforcement is always taken by law enforcement officers, and otherwise avoid inhibition by them (law enforcement). In this case the protection terhaadap legal counsel, especially the implementation of (rights) be avoided because it would hamper the task of other law enforcement, as the opinion as follows: "Law enforcement who run organized by agencies of law enforcement will be such that implementation will giving advantage to those bodies while implementation will give barriers avoided. (Rahardjo, n.d.)

Notch legal counsel rights protection agency less a place as they should, so it would be able to inhibit the task or purpose other law enforcement agencies. Legal counsel in such system function more as a companion, and not an integral part of law enforcement, especially in the SPP (Criminal Justice System).

\section{CONCLUSION}

Based on the discussion concerning the protection function and position of legal counsel in the criminal justice system in Indonesia, can be summed up some of the following; First, legal counsel functions include legal aid, legal assistance and legal service; second, Confidentiality of office advocates / attorneys in fact respected throughout the view of other law enforcement functions are not contradictory; Third, Notch and confidentiality of legal counsel in the office of the Indonesian criminal justice system, tends to be a companion notch. This is evident in some of the provisions of the Criminal Code and the right position more passive and facultative, so it depends on the investigators, prosecutors, and judges; fourth, Protection of the office of legal counsel recognized the extent not inconsistent with the duties of citizens in general and proved to be an employment relationship; Fifth, protection of the rights of legal counsel has not been implemented properly.

\section{BIBLIOGRAPHY}

[1] Adikusumo,R.M.R., 1994, Buku pegangan praktisi hukum (The Lawyewrs Handbook), Citra Aditya Bhakti, Bandung.

[2] Anonoim, 1982, Pedoman Pelaksanaan Kitab Undang-Undang Hukum Acara Pidana, Departemen Kehakiman, Jakarta.

[3] Hamzah, Andi., 1985, Pengantar Hukum Acara Pidana Indonesia, Ghalia Indah, Jakarta.

[4] Harahap, M, 1988, Pembahasan permasalahan dan Penerapan KUHAP, Pustaka Kartini, Jakarta,

[5] Lamintang, P.A.F., 1984, KUHAP dengan pembahasan secara yuridis menurut yurisprudensi dan ilmu pengetahuan hukum pidana, Sinar baru, Bandung.

[6] Lamintang, P.A.F., 1984, KUHP dengan pembahasan secara yuridis menurut yurisprudensi dan ilmu pengetahuan hukum pidana, Sinar Baru, Bandung.

[7] Marpaung, L., Proses penanganan perkara pidana, Sinar Grafika, Jakarta.

[8] Moelyatno, 1985, Undang-undang hukum pidana, Bina Aksara, Jakarta.

[9] Rahardjo, S., n.d., Masalah penegakan hukum, BPHI, Jakarta.

[10] Romadlon, N., 1982, Kitab Undang-undang Hukum Acara Pidana, Liberty, Yogyakarta. 